\title{
芳香・消臭剂の感覚的消臭試験法
}

\author{
森本 祐輔，中村 祐子，皆川 和則，北島幸太郎，長谷川靖之
}

（小林製薬株式会社）

\section{A sensuous deodorization method for air fresheners}

\author{
Yusuke Morimoto, Yuko Nakamura, Kazunori Minagawa, \\ Kotaro Kitajima, Yasuyuki Hasegawa
}

Kobayashi Pharmaceutical Company, Ltd.

\begin{abstract}
Sensuous deodorization, a method to make a person insensitive to odor by using fragrance, is a type of deodorizing method. The method relies on a person's insensitiveness, so the deodorant effect is judged by sensory evaluation. Since the subjectivity of the tester intervenes in the current sensory evaluation, it is difficult to evaluate the deodorant effect of the fragrance itself. To improve the current method, "Density Measurement Method for the Odor Cognition (DMMOC)" was established. In this method, the target odor is diluted with the fragrance, and the deodorant effect can be quantified by the dilution factor where the tester no longer cognizes the odor. Three kinds of air fresheners were examined by the current sensory evaluation and by DMMOC. Although the rank order of the deodorant effect differed in each method, the result of DMMOC corresponded with the result of the consumers' trial. This result indicates that DMMOC is effective for the evaluation of the deodorant effect.
\end{abstract}

(Received 7 March 2012, Accepted 18 September 2012)

Keywords: sensuous deodorization 感覚的消臭, air freshener 芳香 ·消臭剤, sensory evaluation 官能 評価, odor 臭気, cognition 認知, density 濃度

\section{1.はじめに}

現在までに多種多様な芳香・消臭剤が各メーカーか ら発売されている，芳香・消臭剤の種類は用途・剂型 (揮散体) ・香りで大別され，特に香りはその製品ごと に異なるので全く同じ香りは市場には存在せず，製品 の数だけの多様性を持つ.

芳香・消臭郕とはその字の通り, 芳香を発し, 悪臭 を消臭する性能を持つが，その消臭のメカニズムは大 きく 4 つに分類される. 化学的消臭法, 物理的消臭法, 生物的消臭法, そして感覚的消臭法である. 化学的消 臭法は悪臭成分を化学的に分解し, 物理的消臭は悪臭

著者連絡先 yu.morimoto@kobayashi.co.jp
成分を吸着し, 生物的消臭法は悪臭成分を微生物が分 解し, 減少させる消臭方法である. それに対し, 感覚 的消臭法とは芳香・消臭剤の芳香を用いて悪臭を感覚 的に感じなくさせる消臭法である.

感覚的消臭効力は芳香と悪臭の相性により決定する ため, 評価には官能評価を用いる.つまりパネルの感 じ方に個人差があり，同一パネルにおいても評価のた びに変化する心身状態の影響がある，芳香・消臭剤の 開発や評価段階において，パネルの影響により「消臭 効力の高い香り」を選定することが難しいという現状 がある。

そこで本稿ではパネルの「経験」「嗜好」「心身の健 康状態」等に影響されないいわゆる「客観的な」感覚 


\section{芳香・消臭剤の感覚的消臭試験法}

Table 1 「6 段階臭気強度表示法」と「9段階快・不快度表示法」による評価基準

\begin{tabular}{|l|l|}
\hline 臭気強度 & 悪臭の強度 \\
\hline 0 & 無臭 \\
\hline 1 & $\begin{array}{l}\text { やっと感知できるにおい } \\
\text { (険知闘値濃度 })\end{array}$ \\
\hline 2 & $\begin{array}{l}\text { 何のにおいであるかがわかる } \\
\text { 弱いにおい(認知闘値濃度 })\end{array}$ \\
\hline 3 & 楽に感知できるにおい \\
\hline 4 & 強いにおい \\
\hline 5 & 強烈なにおい \\
\hline
\end{tabular}

的消臭効力評価法を設計し，その結果を報告する.

\section{2. 一般的な感覚的消臭効力評価法の特徵と課題}

現在, 芳香 - 消臭剤の感覚的消臭効力試験法として 最も一般的な方法は芳香消臭脱臭剤協議会の自主基準 法（以下，芳消協法）として標準化されている。この 芳消協法は消費者が芳香・消臭剤を家庭で使用する実 空間をラボで再現して試験する方法であり，悪臭と芳 香空気を混合させたサンプルを悪臭しか入っていない ブランクからの改善度で評価する。評価指標としては $\lceil 6$ 段階臭気強度表示法 $($ 無臭〜強烈なにおい)」と「9 段階快・不快度表示法（極端に快～極端に不快)」(石 黒, 2002）（Table 1）を用いて扮り，無臭もしくは快 であるほど芳香・消臭剤としての効力が高いと示され る.この方法には芳香・消臭剂の基礎効力評価が実験 室で簡単に数值化できる長所が存在する反面, 評価指 標には短所が見られ，6段階臭気強度表示法はそもそ も各段階の数值の等間隔性に問題があると考えられて いる（楢崎，2010）。9段階快・不快度表示法はパネ ルの感覚でサンプルのにおいを数值化するため芳香の 嗜好や印象が影響することが容易に想像される。 そこ で我々は以下のような消臭効力評価法を提案する。

\section{3. 客観的な感覚的消臭効力測定法}

\section{1 認知閥值濃度と認知臭気濃度}

嗅覚測定法に「三点比較式臭袋法による臭気濃度表 示法」がある。臭気濃度とはその臭気を無臭空気で希 釈したときに無臭になったと感じるまでに要した希釈 倍数として定義されている. 臭気濃度は臭気の検知可 能・不可能を評価基準としており，パネルの主観が介 入せずに臭気の程度が数值化できるため, 比較的個人

\begin{tabular}{|l|l|}
\hline 快·不快度 & 内容 \\
\hline+4 & 極端に快 \\
\hline+3 & 非常に快 \\
\hline+2 & 快 \\
\hline+1 & やや快 \\
\hline 0 & 快でも不快でもない \\
\hline-1 & やや不快 \\
\hline-2 & 不快 \\
\hline-3 & 非常に不快 \\
\hline-4 & 極端に不快 \\
\hline
\end{tabular}

差が少なく，この希釈倍数の評価基準は官能評価の世 界で広く用いられている（宇都宮，2003）。この臭気 濃度を求める際の「やっと感知できるにおい」の濃度 は検知間值濃度（Table 1 参照）である. 今回提案す る感覚的消臭効力評価法は，この臭気濃度の考え方を 用いて設計している．ここでの感覚的消臭効力が発揮 されている状態とは「対象の悪臭に芳香を混合したと きに混合臭の中の悪臭が，混合する前の悪臭だと判断 できない状態」だと定義する。つまり感覚的消臭法に おける効力有無の境界は，何のにおいであるかが判別 できる点であり, Table 1 より認知閾值濃度である. ここで更に我々は認知閾值濃度に達するまでに要した 空気の希釈倍数を認知臭気濃度, これを判断基準に用 いた感覚的消臭効力試験法を認知臭気濃度法と定義す る。また希釈に用いる空気として，無臭空気を用いた ときと芳香空気を用いたときの希釈倍数，つまり認知 臭気濃度の差をその芳香空気の感覚的消臭効力值と定 義する.

認知臭気濃度は，対象悪臭を任意の空気で段階希釈 したサンプルを使用して求める。試験悪臭は何が用い られているかをパネルには知らせず試験を開始する. 悪臭を任意の空気で何段階かの濃度に希釈したサンプ ルを用意し，悪臭に対して順応が起きぬように悪臭濃 度が低いサンプルから官能評価を始め, 段階的に悪臭 濃度が高いサンプルの評価を実施する。試験悪臭の種 類が認知できる悪臭濃度にするために要する希釈倍数 がその空気の試験悪臭に対する認知臭気濃度である.

認知臭気濃度法は以下の 2 段階で構成される。
a）感覚的消臭効力評価
b）パネル選定

a）の感覚的消臭効力評価は悪臭を認知可能なサン 
プルを選択することで希釈倍数を求めるために， b) のパネル選定はサンプルの中に含まれる悪臭を認知で きているかの確認のために行われる.

前述の方法で認知臭気濃度を求める過程が a）とな るが，正しく試験悪臭を認知できていることを確認す るために，別途用意した選択肢悪臭の中から a）で感 知した悪臭を選択して b）のパネル選定とする。ここ で正しい悪臭を選択できなかったパネルは不適格パネ ルとし，正しい悪臭を選択して認知できたことを確認 した適格パネルの認知臭気濃度の平均值のみを結果に 採用する。このパネル選定法は対象悪臭への特異的無 嗅覚症者だけでなく, 試験時の体調不良や精神的不安 定による一時的無嗅覚症者等を排除した試験結果が得 られる。このように適切なパネル選定が可能なだけで なく,さらにパネル選定と消臭効力測定が同時に行え， パネルの意思を含まずに消臭効力が数值化できる，そ のため臭気判定士や嗅覚テスト合格者がパネルとして 必ずしも必要ではないという長所がある.

\section{2 試験方法}

芳消協法と認知臭気濃度法で芳香・消臭剤の感覚的 消臭効力順を評価した。評価サンプルは同じ揮散構造 で, 水, 香料, 界面活性剂, 消臭剂, 色素から構成さ れる香りが異なる 3 種類の置き型芳香・消臭剤（シト ラス：A・ミント：B・ラベンダー：Cの芳香) を使 用した. 各 $10 \mathrm{~L}$ テドラーバッグ（GLサイエンス）に 通常使用状態の各芳香・消臭剂を入れ，クリップで封 をし，エアーポンプで吸引脱気した後，無臭空気を $5 \mathrm{~L}$ 送り込んで室温で 60 分間静置した。その後, 飽和 状態となった芳香空気のみを別のテドラーバッグに移 し取り芳香マスターバッチとしてそれぞれの試験で用 いた。 なお，以下の手順では特別な記載が無い限り， 空気を送り込む前にはクリップで封をし，エアーポン プで脱気を行うこととする.

試験対象悪臭としては管理しやすい実悪臭という理 由からタバコの悪臭を用いた。まずエアーポンプ (KNF Neuberger) でマイルドセブン（JT）のフィ ルターを吸引しながら 10 秒間燃焼させた後, $140 \mathrm{ml}$ 汎用ガラス瓶の中で消火してフ夕を閉めた．次に沉用 ガラス瓶を $10 \mathrm{~L}$ テドラーバッグに入れ，無臭空気を $5 \mathrm{~L}$ 送り込んだ。テドラーバッグ内で夕バコの入った 汎用ガラス瓶のフタを開け，60 分間室温に静置し余 煙を収集して最後に再びフ夕を閉めた。こうして作製 した悪臭マスターバッチを希釈してそれぞれの試験で
用いた．以下，この悪臭マスターバッチを希釈したサ ンプルのにおいをタバコ悪臭と呼ぶ.

\section{I ）芳消協法による消臭効力順評価}

I-1）芳香空気の調整

10L テドラーバッグに芳香マスターバッチの芳香空 気を $5 \mathrm{~L}$ 送り込んだ.

\section{I -2）悪臭希釈濃度の調整}

悪臭マスターバッチから試験悪臭を $20 \mathrm{ml}$ 採取して 無臭空気で全量 $5 \mathrm{~L}$ となるように希釈 (250 倍希釈) すると臭気強度 4 程度となった. 芳消協法では試験悪 臭の初期臭気強度は 3〜 4 と推奨されているため（芳 香消臭脱臭剤協議会, 2011)，これを悪臭のブランク とした，そのため I-1）で調整した芳香空気と, 悪臭 マスターバッチの試験悪臭を $20 \mathrm{ml}$ 混合させて全量 5Lの試験サンプルを作製した.

\section{I -3）官能評価}

パネルに対して試験に用いる悪臭がタバコ悪臭であ ると予め知らせて扮き, 芳香消臭脱臭剂協議会で定め られている自主基準法に則って悪臭ブランクと 3 サン プルに対して「6段階臭気強度表示法」と「9段階 快・不快度表示法」の指標で評価した。試験は $\mathrm{n}=11$ で行い, パネル全員が嗅覚テスト合格者であり,この 中には臭気判定士も 1 名含まれていた.

\section{II ）認知臭気濃度法による認知臭気濃度測定}

\section{II-1）芳香空気の調整}

まずサンプルの芳香空気の調整を行った。 今回は芳 香・消臭剤を一般的な 4.5 睤室内に置いた時と同程度 の芳香強度となるように, 芳香マスターバッチから $100 \mathrm{ml}$ 採取して無臭空気で全量 $5 \mathrm{~L}$ となるように希釈 （50 倍希釈）したサンプルを 6 つ用意した。 その際 3 種類の芳香空気の芳香強度が同程度であることを確認 した。

\section{II -2）覀臭希釈濃度の調整}

II -1）で芳香濃度を調整したテドラーバッグに, 悪 臭マスターバッチから 2000 倍, 1000 倍, 500 倍, 250 倍, 125 倍希釈の悪臭濃度となるように悪臭量を注入 し，5段階の悪臭希釈濃度サンプルを作製した。悪臭 を注入していないテドラーバッグサンプルは芳香のブ ランクとした。 


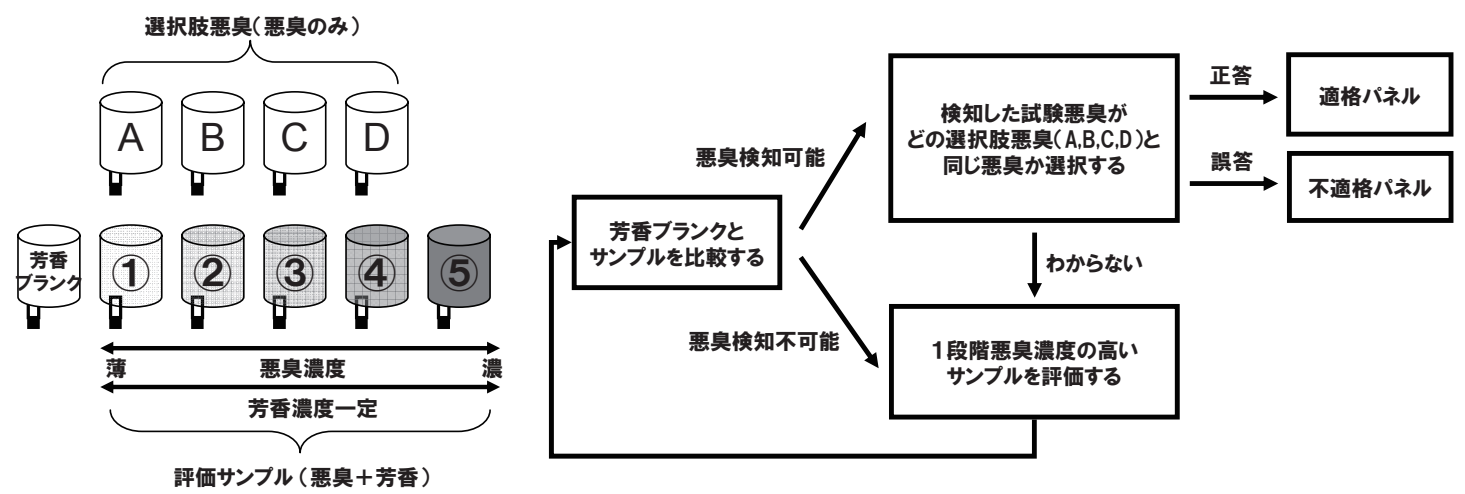

Figure 1 認知臭気濃度法を用いた感覚的消臭試験イメージ （左：試験開始時に準備された試験サンプル，右：試験手順フロー）

II -3）選択肢悪臭の調整

上記とは別途, 選択肢悪臭サンプルとして臭気強度 3 程度の悪臭 (酢酸, アンモニア, メチルメルカプタ ン, タバコ悪臭マスターバッチを無臭空気で 500 倍希 釈したサンプル）を用意した.

\section{II -4）官能評価}

パネルは悪臭濃度の低い 2000 倍希勫のサンプルか ら, 適時芳香ブランクと比較しながら臭気の有無の評 価を行い，悪臭を感じ取れる濃度のサンプルになるま で順に評価を行った（Figure 1)。悪臭を感じ取るこ とができたサンプルと 4 種の選択肢悪臭の嗅ぎ比べを 行い, サンプルに含まれる悪臭がどの選択肢悪臭と同 じものであるかを選択する。ここでは最も悪臭濃度が 低く，かつタバコ悪臭だと認知できたサンプルを選ぶ ことを目標とした。ただし試験の正確性向上のため, 悪臭濃度が高いサンプルを評価した後でありながら, それよりも低い悪臭濃度サンプルで既に認知できてい たと答えることは出来ないこととした．前述の通り, 正しく悪臭を認知できたパネルを適格パネルとして認 知臭気濃度の平均值を算出し, 比較した。 シトラスの 芳香による試験は $\mathrm{n}=17$, ミントの芳香による試験は $\mathrm{n}=18$, ラベンダーの芳香による試験は $\mathrm{n}=16$ で行った.

また以上の試験（芳消協法, 認知臭気濃度法シトラ ス，ミント，ラベンダーの全 4 試験）はパネルへの影 響も考えて全て異なる日に行った。

\section{III）消費者モニター}

芳香・消臭剤の香りの評価が及ぼす, 感覚的消臭効 カへの影響を調査するため，一般消費者に対してモニ
ター試験を行った，試験サンプルは芳消協法，認知臭 気濃度法で評価したシトラス, ミントの香りの芳香・ 消臭剂を使用した。なお，官能評価結果（後述）から 双方で結果が一致したラベンダーの香りは除外した。 対象者は家庭に契煙者がいる夕バコ用液体芳香・消臭 剂使用意向者で, シトラスの香りは $\mathrm{n}=27$, ミントの 香りは $\mathrm{n}=30$ に対してそれぞれ実施した．4週間の使 用後に「香りの嗜好性」「香りの㧍部屋合致度」「タバ コ悪臭への消臭効果」の項目についてのアンケートを 回収した。

\section{3 実験結果}

I ）芳消協法による消臭効力順評価結果

芳消協法による消臭効力順評価結果を Figure 2 に 示す。「6段階臭気強度表示法」の指標では悪臭ブラ ンクの臭気強度 3.72 から芳香・消臭剂使用後の数值 はシトラスが 2.50 ，ミントが 2.11 , ラベンダーは 1.55 段階の改善度が見られた。「9段階快・不快度表示法」 の指標では悪臭ブランクの快・不快度 -1.67 から芳 香・消臭剂使用後の数值はシトラスが 1.73 , ミントが 1.23 , ラベンダーは 0.84 段階の改善度が見られた。芳 消協法での感覚的消臭効力順は「シトラス $>$ ミント> ラベンダー」となった。

II ）認知臭気濃度法による感覚的消臭効力順評価結果 認知臭気濃度法での感覚的消臭効力試験結果を Figure 3 に示す. シトラスの芳香のパネル $\mathrm{n}=17$ の うち 9 名, ミントの芳香は $\mathrm{n}=18$ のうち 16 名, ラベ ンダーの芳香は $\mathrm{n}=16$ のうち 10 名が正しく悪臭を認 知しており適格パネルと判断できた。認知臭気濃度平 

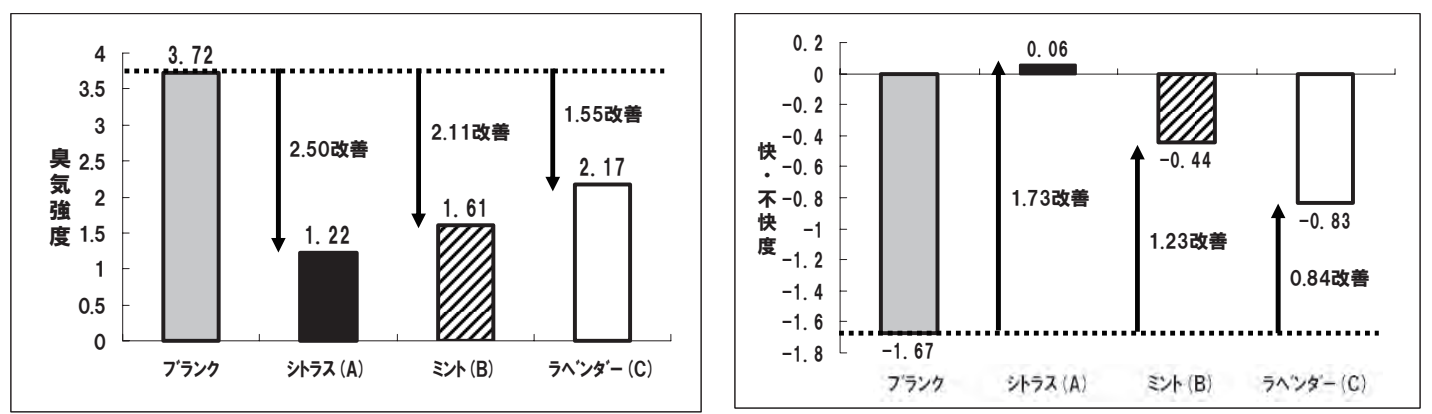

Figure 2 芳香消臭脱臭剤協議会自主基準法（芳消協法）による感覚的消臭効力試験結果（n=11）

(左：6段階臭気強度表示法 右 : 9 段階快・不快度表示法)

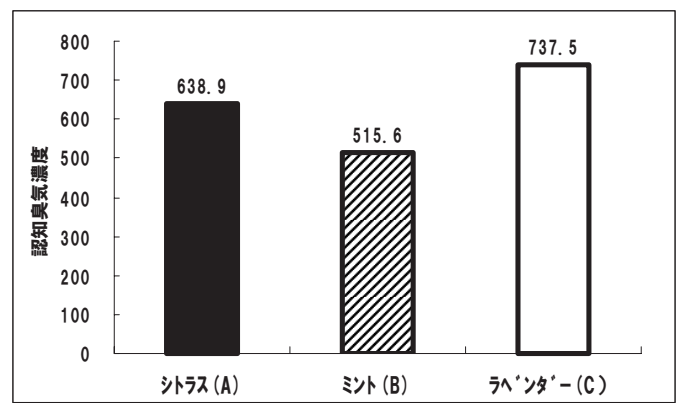

Figure 3 認知臭気濃度法による感覚的消臭効力試験結果 $(\mathrm{A}: \mathrm{n}=17, \mathrm{~B}: \mathrm{n}=18, \mathrm{C}: \mathrm{n}=16$ で行い, 適格 パネルは $\mathrm{A}: \mathrm{n}=9, \mathrm{~B}: \mathrm{n}=16, \mathrm{C}: \mathrm{n}=10$ )

均值はシトラスの芳香が 638.9, ミントの芳香は 515.6, ラベンダーの芳香は 737.5 であり, 認知臭気濃度法で の感覚的消臭効力順として「ミント>シトラス>ラベ ンダー」という傾向が見られた。

III）消費者モニター結果

消費者モニターの各質問項目の結果をグラフ化し， Figure 4 に示す。「香りの嗜好性」「香りのお部屋合 致度」の 5 段階評価のうち最も上位の「好き」「合つ ている」の結果についてはシトラス $48.1 \%$ ，ミント 40.0\%となった。また「タバコ悪臭への消臭効果」の 5 段階評価のうち最も上位の「良い」に関してはシト ラス $40.7 \%$ ，ミント $50.0 \%$ という結果になった。

\section{4 考察}

芳消協法, 認知臭気濃度法で, 芳香・消臭剂に汎用 されている 3 種類の香りの, タバコ悪臭に対する感覚 的消臭効力試験を実施した。その結果，芳消協法では 消臭効力がシトラス $>$ ミント >ラベンダーの順, 認知

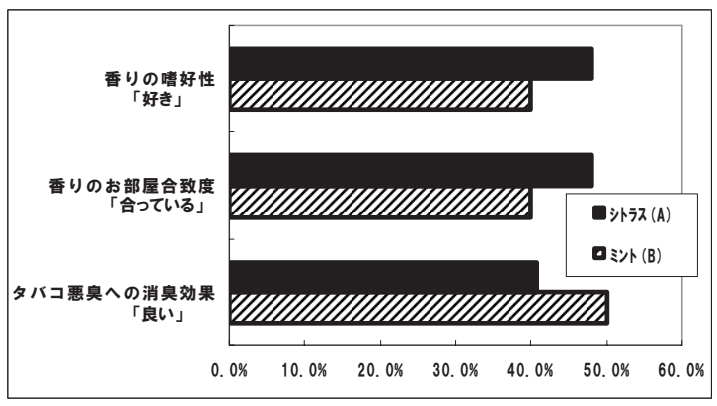

Figure 4 シトラス $(\mathrm{A})$, ミント（B) における消費者モニ ターの結果 $(\mathrm{A}: \mathrm{n}=27, \mathrm{~B}: \mathrm{n}=30)$

臭気濃度法ではミント>シトラス $>$ ラベンダーの順と なり, 結果が一部逆転した。 この結果について, 先に 示した消費者モニターの結果より考察する．消費者モ ニターにおけるシトラスの香りの嗜好性・お部屋合致 度評価は「好き」「合っている」が共に $48.1 \%$ であり， ミントの香りは共に $40.0 \%$ であった。従ってシトラス は，ミントよりも一般的に「快」と評価される香りで あると言える，よって評価指標が快・不快を尺度とす る芳消協法に抢いてはパネルの主観評価が介在したた め, シトラスの評価結果がミントを上回った可能性が 示唆される。一方, 消費者モニターによるシトラスの 香りの消臭効力評価は「良い」が $40.7 \%$ ，ミントは $50.0 \%$ であり結果に逆転が生じた。これは認知臭気濃 度法の結果とも合致しており，ミントはシトラスより も低濃度で夕バコ悪臭を感覚的に無臭化させることが 可能な香りであると考えられる. 以上の結果より, 芳 香・消臭剤の開発においてその効力を評価する場合, 主観を含めた芳消協法と主観を含まない認知臭気濃度 法を上手く組み合わせることが望ましいと考えられる。 次に認知臭気濃度法より得ることが出来るその他の 


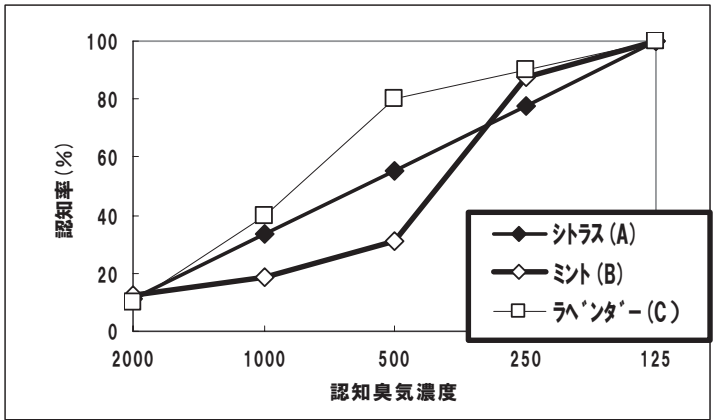

Figure 5 各試験サンプルにおける認知臭気濃度と認知率 の関係

知見について以下に考察する。認知臭気濃度法には, 消臭に関する香りの特徵や悪臭に対する香りの相性が 分かるという長所も存在する. 悪臭の各希釈倍数にお ける認知率（悪臭を認知できたパネルの適格パネル全 体における割合）を Figure 5 に示す，Bのミントは タバコ悪臭に対して相性がよい香りであるということ は先に示したが, タバコ悪臭の希釈倍数が 500 倍を下 回ると認知率が急激に増加した。一方 Aのシトラス の香りは悪臭濃度が高くなるに従って徐々に認知率が 増加した。またCのラベンダーの香りは，比較的悪 臭濃度の低い段階から認知率が高く, タバコ悪臭との 相性が悪いと言える。ここで各香りの感覚的消臭効力 差が確認しやすいように, 芳香空気で 2000～500 倍希 釈したときまでの認知率を Figure 6 に示す. 最も大 きな効力差を確認できた B のミントと Cのラベン ダーの香りの間には $\mathrm{p}<0.05$ の有意差が認められ, 確 かにミント>シトラス >ラベンダーという感覚的消臭 効力順の傾向が見られた．以上より今回提案する認知 臭気濃度法は, 悪臭と香りの相性の良し悪しが評価で きるだけでなく，香りによる特徴の違いも確認できる 方法である点も優れていると考えられる.

\section{4. おわりに}

芳香・消臭剤の開発・評価において認知臭気濃度法 は有用な方法の一つであると考えられる。この方法を 用いると, 消臭効力の高い香料の開発・評価・選定が 可能となり，ょり一般消費者に満足してもらえる芳

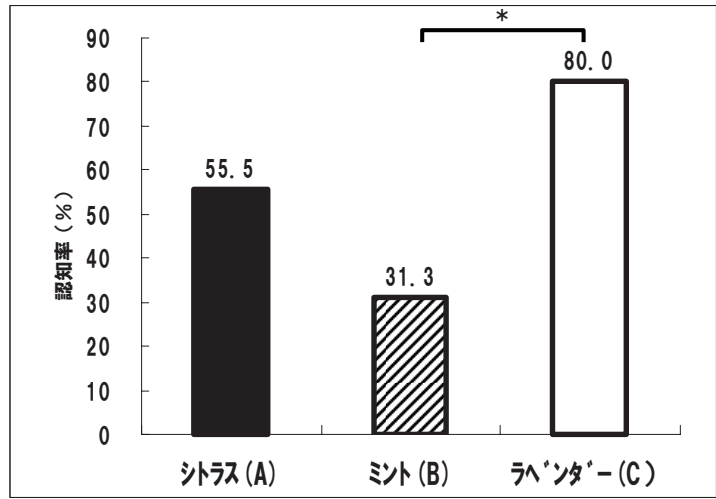

Figure 6 各試験サンプルの認知臭気濃度 500 以上におけ る認知率

$(\mathrm{A}: \mathrm{n}=17, \mathrm{~B}: \mathrm{n}=18, \mathrm{C}: \mathrm{n}=16$ で行い, 適 格パネルは $\mathrm{A}: \mathrm{n}=9, \mathrm{~B}: \mathrm{n}=16, \mathrm{C}: \mathrm{n}=10)$ * : p $<0.05$ (Fisher 正確検定)

香・消臭剤が開発可能となる．またその香りの消臭特 徵に合致した環境で使用してもらい，より高い効果を 実感してもらえるので使用者満足度を向上させること も期待できる.しかし一方で，芳香・消臭剤は最終的 に一般消費者が使用するものであるので香りの嗜好性 等を反映させた製品でなければならない，認知臭気濃 度法は客観的な消臭効力は評価可能だが，香りの嗜好 性などは反映されないので別途消費者テストによる確 認が必要である，以上より芳香・消臭剤の開発段階に よって「認知臭気濃度法」「芳消協法」「消費者モニ ター」を使い分けることで，その製品に相応しい消臭 効力を持つ「香り」を評価・選定していくことが必要 であると考えられる。

\section{引用文献}

石黒辰吉（2002）臭気の測定と対策技術, オーム社, 東京, pp. 15.

楢崎正也（2010）におい基礎知識と不快対策・香りの 活用, オーム社, pp. 86-90.

宇都宮仁（2003）清酒官能評価パネルの選抜・訓練法, 醸協, pp. 317.

芳香消臭脱臭剤協議会（2011）一般消費者用 芳香 ·

消臭・脱臭剂の自主基準, 実施要領. 